\title{
Irish Veterinary Journal goes open access
}

\author{
Michael L Doherty
}

As Editor-in-Chief, I am delighted to announce the relaunch of Irish Veterinary Journal with BioMed Central, The Open Access Publisher, as part of their increasing veterinary portfolio. This is indeed an historical moment in the history of Irish Veterinary Journal, which was first published in November 1946. In this electronic age that we live in, it is interesting to note that the publication of the first issue was delayed by a post-war shortage of paper.

The first scientific paper published in the Irish Veterinary Journal was a study of blood serum parameters in cattle, horses, sheep and pigs in Ireland by W. Burke McAleer; a paper that emerged from his $\mathrm{PhD}$ thesis in the Veterinary College in Dublin. In its early years an editorial committee managed the journal and there was no mention of an individual Editor until the mid-1960s when J.K. Kealy was listed officially as Editor. B.T. Farrelly, who presided over the IVJ until 1980, soon followed him. Dr. Pat Hartigan became Editor in 1981 and worked tirelessly as peer-review Editor for many years until 2006. Management of publishing over this period was carried out by Irish Veterinary Publications Ltd. and more recently by IFP Media Ltd. for the new Veterinary Ireland organisation.

The move to Biomed Central heralds an exciting chapter in the history of the journal. Irish Veterinary Journal, with the support of Veterinary Ireland - the Irish professional representative organisation, is delighted to become part of the greater BMC publishing family and hopes to offer a new voice for high quality veterinary research internationally. Along with my Deputy Editors, Simon More, John Mee and Grace Mulcahy and expert editorial board, I would like to wish the new Irish Veterinary Journal every success.

Guim gath rath ar Iris Tréidliachta Eireann nua!

Michael Doherty

Editor-in-Chief

Irish Veterinary Journal

Correspondence: michael.doherty@ucd.ie

School of Agriculture, Food Science and Veterinary Medicine, University College Dublin, Belfield, Dublin 4, Ireland
Received: 4 March 2011 Accepted: 31 March 2011

Published: 31 March 2011

doi:10.1186/2046-0481-64-1

Cite this article as: Doherty: Irish Veterinary Journal goes open access. Irish Veterinary Journal 2011 64:1.
Submit your next manuscript to BioMed Central and take full advantage of:

- Convenient online submission

- Thorough peer review

- No space constraints or color figure charges

- Immediate publication on acceptance

- Inclusion in PubMed, CAS, Scopus and Google Scholar

- Research which is freely available for redistribution

Submit your manuscript at www.biomedcentral.com/submit

\section{() Biomed Central}

